\title{
LGALS7B wt Allele
}

National Cancer Institute

\section{Source}

National Cancer Institute. LGALS7B wt Allele. NCI Thesaurus. Code C90330.

Human LGALS7B wild-type allele is located in the vicinity of 19q13.2 and is approximately $3 \mathrm{~kb}$ in length. This allele, which encodes galectin-7 protein, is involved in the modulation of keratinocyte adhesion and apoptosis. 